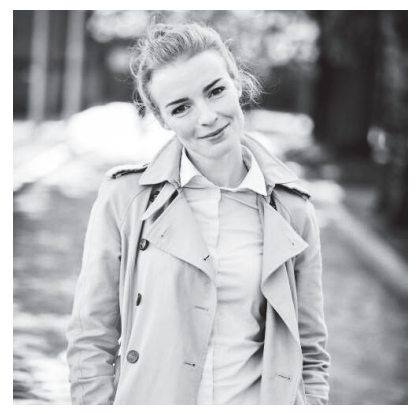

Arina Ivanickaja - Klaipėdos universiteto doktorantė. Moksliniai interesai: kuršininkų kalba, baltų kalbos, lyginamoji kalbotyra.

El.paštas: arinadergen@gmail.com

Arina Ivanickaja: PhD student, Klaipeda university. Research interests: Kursenieku language, Baltic languages, Comparative linguistics.

E-mail: arinadergen@gmail.com

\title{
Arina Ivanickaja
}

\author{
Klaipedos universitetas
}

\section{ADALBERTAS BEZZENBERGERIS - KURŠININKŲ KALBOS TYRĖJAS IR DOKUMENTUOTOJAS}

\section{Anotacija}

XIX-XX a. sandūroje Prūsijoje augo susidomèjimas ịvairių tautinių grupių etnokultūriniu savitumu. Žymus baltų kalbų tyrèjas, etnografas ir archeologas prof. Adalbertas Bezzenbergeris daugiau kaip keturiasdešimt metų siejo savo veiklą su Kuršių nerija, daug dėmesio skirdamas gyvenviečių istorijai, papročiams ir kuršininkų kalbai. Jo darbas „Apie Prūsijos latviu kalbą“" (Über die Sprache der preußischen Letten) (1888) tapo pirmąja profesionalia kuršininkų kalbos studija. Joje ne tik pagal to meto lyginamosios kalbotyros tradiciją parengtas kuršininkų kalbos aprašas, grịstas gausia faktine, paties tyrejjo surinkta medžiaga, bet ir keletas tekstų pavyzdžių bei žodynèlis. Kadangi kuršininkų kalba neturejjo rašto, kiekvienas jos dokumentuotojas, tarp ju ir A. Bezzenbergeris, naudojo savo rašybos sistemą. Šis darbas svarbus to meto kuršininkų kalbos būklès rekonstrukcijai bei apskritai šios kalbos istorijos tyrinejjimams.

Straipsnyje pateikiamas A. Bezzenbergerio indèlio dokumentuojant kuršininkų kalbą vertinimas bendrame kuršininkų kalbos rašytinių šaltinių kontekste, siekiama įžvelgti kalbos raidos tendencijas, atskleidžiamas skirtingų laikotarpių šaltiniuose.

PAGRINDINIAI ŽODŽIAI: kuršininkų kalba, rašytinis paminklas, nykstanti kalba, dokumentavimas, baltistika.

\section{Abstract}

In the period of the $18^{\text {th }}$ and $19^{\text {th }}$ century, the interest in the ethno-cultural identity of various ethnic groups had begun to grow in Germany. For more than forty years a fa- 
mous researcher of Baltic languages, ethnographer and archaeologist prof. Adalbert Bezzenberger focused his activities on the Curonian Spit by devoting his attention to the history and culture of the settlements and the endangered Kursenieku language. His work "Über die Sprache der preußischen Letten" (1888) became the first professional study of the Kursenieku language. Not only does the work contain a description of the Kursenieku language prepared in accordance with the tradition of comparative linguistics of that time, and is based on a large amount of factual materials accumulated by the investigator himself, but it also includes a number of texts and a glossary. Since the Kursenieku language did not have a written form, every documenter, including Bezzenberger, used one's own system of spelling. This work is important for the reconstruction of the Kursenieku language of that time, as well as for the overall research of the history of the language in general.

The article presents the assessment of Bezzenberger's contribution to documenting the Kursenieku language in the general context of written sources of the Kursenieku language, it also aims at discerning the tendencies of language development reflected in sources of different chronological periods.

KEY WORDS: Kursenieku language, written monument, endangered language, language documentation, baltistics.

doi:http://dx.doi.org/10.15181/rh.v24i0.1909

XV-XVIII a. Kuršių nerijos teritorijoje susiformavo geolektas, kuris atkeliavo kartu su persikèlèliais iš Kuršo. Tuo metu Kuržemėje jau buvo pereita prie latvių kalbos, tačiau atsiskyrę nuo tèvynainių Prūsijos kuršininkai išsaugojo daugeli senosios kuršių kalbos archaizmų ir refleksų. Šiandien ši kalba dažniau laikoma latvių kalbos dialektu' ${ }^{1}$. Tačiau būdami

1 Pèteris Vanagas (Vanags 1999, 117-118), svarstydamas, kurią sąvoką reikia vartoti kalbant apie kuršininkų tarmę, teigia, kad atsakymas priklauso nuo kriterijų, kuriais remsimès. Jei pagrindiniais veiksniais laikysime tai, kad: 1) kuršininkų tarmé atsirado (t. y. genetiškai susijusi) iš latvių kalbos dialekto; 2) jos morfologinè struktūra ir fonetinè sistema mažai kuo skiriasi nuo latvių kalbos; 3) tarmès funkcionavimo laikotarpiu Kuršių nerijos ir Latvijos gyventojai galejo lengvai suprasti vienas kitą be trečios kalbos pagalbos, suvokdami, kad kalba viena kalba - ,kursisk(a) valuod(a)“ (latvių kalba); tuomet galima teigti, kad kuršininkų tarmè yra latvių kalbos dialektas. Tačiau jei svarbesniais veiksniais laikysime tai, kad: 1) Kuršiu nerijos kalba buvo stipriai veikiama vokiečių ir lietuvių kalbų; 2) tarmèje nėra didžiosios dalies jos kultūros leksikos, kuri vartojama latvių kalboje, vietoj jos dažniausiai vartojami vokiški arba lietuviški pavadinimai; 3) Kuršių nerijos gyventojai politikos, o svarbiausia - teritorijos atžvilgiu buvo atskirti nuo kitų žemių, kuriose gyveno latviai, 4) kuršininkų tarmẻ buvo vienos iš Rytų Prūsijos etninių mažumų kalba, genetiškai skirtinga nuo kitų regione funkcionavusių kalbų (vokiečių, lietuvių, kašubų, mozūrų), todèl negalèjo būti regioniniu jų dialektu - tada galima kalbėti apie Kuršių nerijos kalbos savarankiškumą. Tokiu atveju jai galima taikyti kalbos funkcinio varianto terminą idioma (angl. Idiom: Crystal 2005, 17), nors lietuvių lingvistikoje šia reikšme paprastai vartojamas terminas kalba (plg. jaunimo kalba, plungiškių kalba, jūrininku kalba). 
Prūsijos, o vèliau Vokietijos ir pagaliau Lietuvos valstybės piliečiai Kuršių nerijos kuršininkai perėmè minètų etninių kultūrų ir kalbų ypatybių. Atsiskyrusi nuo Kuržemės dialektų kuršininkų kalba vystėsi savarankiškai, be to, buvo vartojama ir socialiai, ir etniškai gana uždaros žvejų bendruomenès buitiniams, etninès kultūros ir verslo poreikiams. Ši žvejų kalba niekada netapo oficiali ir neįgijo rašto. Tačiau būta bandymų ją fiksuoti raštu, naudojant įvairius kitų kalbų rašmenis.

Kuršininkų kalbos dokumentavimą XVIII a. pradejjo etnografai ir lingvistai, kurių didžioji dalis - vokiečiai, XX a. pradžioje į darbą įsitraukè latviai, o lietuviai jai dèmesio skirti pradejjo XX a. pabaigoje (Vanags 1999; Kiseliūnaitè, Schiller 2015).

Kuršininkų kalbos dokumentavimo istorija prasidejo nuo XVIII a. Rusijoje dirbusio vokiečiu kilmès mokslininko Peterio Simono Pallaso, į savo žodyną Linguarum totius orbis vocabularia comparative augustissimae cura collecta, išleistą 1787-1789 m., ittraukusio 278 kuršininkų žodžius, kuriuos jis klaidingai priskyrẻ Livonijos krivičių kalbai (krivingo-livonskij) (Ivanickaja 2017, 16-17). 1879 m. ị Georgo Wenkerio rengiamą Vokietijos kalbų atlasą (Der Deutsche Sprachatlas) buvo ịtraukta kuršininkų kalbos kortelè Nr. 30084, kurią sudare tekstų (sakinių) rinkinys (plačiau apie ši šaltinị Kiseliūnaitè, Schiller 2015).

Profesoriaus Adalberto Bezzenbergerio darbas „Apie Prūsijos latvių kalbą“ (Über die Sprache der preußischen Letten) laikomas pirmąja profesionalia kuršininkų kalbos studija. Nuo XVIII a. moksle išryškejjo tiesioginè kalbos ir tapatybės sąsaja. Tai buvo susiję su nacionalizmo ideologija, ypač Rytuc ir Vidurio Europoje, skatinusia mokslininkus studijuoti tam tikro tautinio subjekto kalbą, kultūrą ir istoriją. Su A. Bezzenbergerio vardu šiandien siejami pirmieji tiksliniai moksliniai lietuvių, latvių ir prūsų kalbų, kaip lyginamosios kalbotyros objekto, tyrimai. Rytų Prūsijos kalbos ir kultūros tyrinejjimams A. Bezzenbergeris skyrẻ daugiau nei 40 metų, pradejjęs tada, kai Vokietija buvo ką tik politiškai susivienijusi ir èjo nacionalinès valstybės stiprinimo keliu. Šis procesas ne tik gilino jau XIX a. nevokiškų etnosų asimiliaciją, bet ir įvedè naują, griežtesnę dimensiją visišką tautinių mažumų niveliaciją germanizacijos forma (Strakauskaitė 2011, 148). Matydami, kad mažumų kalboms gresia išnykimas, lyginamosios kalbotyros atstovai suskubo jas dokumentuoti ir aprašyti mokslo tikslais. Todèl ị Karaliaučiaus universiteto profesoriaus A. Bezzenbergerio 
mokslinị akiratị pateko ir kuršininkai, kurie, būdami Rytų Prūsijos etninė mažuma, išsiskyrẻ savo kultūriniu ir kalbiniu savitumu.

Studijoje „Kuršių nerija ir jos gyventojai“ (Die Kurische Nehrung und Ihre Bewohner), išleistoje 1887 m., A. Bezzenbergeris išsamiai aprašo Kuršių nerijos ir jos gyventojų raidą, pasitelkdamas įvairius ankstesnius istorikų, geografų, geologų darbus, bažnyčių knygas. Kalbai šiame darbe A. Bezzenbergeris skyrè vieną skyrių (Bezzenberger 1887, 253-279), kuriame trumpai pristato kuršininkų kalbos padètị tarp kitų kalbų, apžvelgia kalbų sąveiką, gyventojų statistiką pagal pavardes, šiek tiek aptaria fonetiką, nukreipdamas skaitytoją i kitą savo darbą - „Apie Prūsijos latvių kalbą“ (išleistą 1888 m.), kurị jis skyrẻ kuršininkų kalbai.

Studija „Apie Prūsijos latvių kalbą“ susideda iš tuo metu gana išsamaus fonetinių, morfologinių ir leksinių ypatybių aprašo, joje pateikti nerijos kuršininkų tarmės pavyzdžiai lyginami su Melnragès ir Karklès kuršininkų kalbos pavyzdžiais. A. Bezzenbergeris yra vienintelis kuršininkų kalbos dokumentuotojas, spejjęs užfiksuoti kalbos pavyzdžių iš pietinės Kuršių nerijos dalies (Pilkopos, Rasytės, Kuncu), kuri dabar priklauso Rusijai, bet jau ir tuomet jam bepavyko rasti vos keletą kalbètojų, ta nerijos dalis jau buvo suvokietejjusi (Bezzenberger 1888, 3).

Knyga prasideda nuo įžangos, kurioje autorius pristato kalbą ir savo darbo eigą bei informacijos pateikimo formą. A. Bezzenbergeris laiko Kuršių nerijos gyventojų kalbą latviška, bet pažymi, kad patys save jie vadina Kuren, o kalbą - kurische, todèl ir jis savo pateikiamuose statistiniuose skaičiavimuose taip pat vartoja terminus Kuren, o kalbą vadina kurische Sprache (arba preußifch-lettifchen Sprache).

Nors G. Wenkerio atlasui surinkta medžiaga buvo kiek ankstesnè (1879), tačiau, matyt, A. Bezzenbergeris apie ją nieko nežinojo ir knygoje neužsimena, todèl autorius naudojosi savo paties medžiaga, surinkta iš pateikejjų ekspedicijose. Viena svarbiausių jo pagalbininkių buvo mergaitė iš Nidos Lotte Falk, kuri daug metu dirbo tarnaite jo vasarnamyje. Ji padẻjo pagrindą jo žinioms apie kuršininkų kalbą, iš jos A. Bezzenbergeris sužinojo apie tarimą ir žodžiu darybą. Lotte buvo kuršininko ir lietuvès dukra, jų šeimos kalba buvo kuršininkų. Mergaitė niekada nebuvo išvykusi iš Nidos, todèl buvo patikima pateikejja. Knygoje gausu pavyzdžių, jie sudaro didžiąją knygos teksto dalį, prie kiekvieno pavyzdžio pridèta pateikejjo santrumpa: vardas, pavardè arba gyvenamoji vieta (žr. skyrių Morfo- 
logija-skaitvardžiai). Svarbiausia A. Bezzenbergeriui buvo dokumentuoti kuo gausesni kiekị kalbos faktų, pasidalyti surinkta informacija. Jis daug argumentuoja, lygina su lietuviu ir latvių kalbų faktais, tačiau knygoje daugiau prielaidų negu išvadų. Autorius toki pirminị siekį nurodo ir darbo izžangoje: " $<\ldots>$ bemerke ich indessen, dass ich von vornherein gar nicht beabsichtigt habe, ein bis in's Einzelste ausgearbeitetes Bild jener Sprache zu liefern, vielmeht wollte ich eigentlich nur die Grundlinien desselben kundig ist, an seiner Ausführung mitarbeiten könnte. Mein Interesse an der Sache hat mich dann aber über dies Ziel hinausgeführt, und so gebe ich mehr, als ich ursprünglich wollte, und würde noch mehr gegeben haben, wenn ich nicht in den nächsten Jahren weitab liegende Verpflichtungen einzulösen hätte. Von großen Belang sind die betreffenden Lücken übrigens nicht”.

Autoriaus kruopštumą ir kompetenciją rodo darbe esantys gausūs komentarai, išnašos, kurios kartais užima daugiau vietos už pagrindinị tekstą. Šiuose komentaruose A. Bezzenbergeris pateikia daug papildomų pavyzdžių, palyginimų su kitais šaltiniais, fonetinių ir morfologinių variantų.

\section{Rašyba}

Savo darbuose apie kuršininkų kalbą A. Bezzenbergeris naudoja lietuvių, vokiečiu ir latvių rašybos ženklus. Ǐžangoje jis trumpai pristato ortografiją, nukreipdamas skaitytoją i i savo paties anksčiau (1885 m.) parašytas „Latvių kalbos tarmių studijas“ (Lettische Dialekt-Studien), kuriose išsamiau pristato, kodèl ir kaip pasirinko tokị užrašymo būdą. Spręsdamas ši klausimą A. Bezzenbergeris rẻmėsi ir kitų mokslininkų darbais: Georgo Mancelijaus latvių kalbos studija, kurios autorius naudojasi vokiečių kalbos rašybos ženklais, ir Augusto Bielensteino „Latvių kalba“ (Lettische Sprache). İžanginejje studijos „Apie Prūsijos latvių kalbą“ dalyje A. Bezzenbergeris gana detaliai paaiškina savo darbo principus: pažymi, kad pateike tik žodžius, kuriuos girdejjo du ar daugiau kartų, norėdamas užfiksuoti jų tikslų tarimą. Jam pavyko gana detaliai atspindèti kuršininkų tarmès fonetiką. Balsiams žymèti A. Bezzenbergeris naudoja įvairius diakritikus, siekdamas kuo tiksliau nurodyti balsio ilgumą ir artikuliaciją. Balsių ilgumui žymėti naudojami ženklai kartu nurodo ir priegaidę (gâja: ilgas balsis, tęstinè priegaidè - klát: ilgas balsis, stumtinė priegaidė; plg. dar grîsti-trís; mûsu-grúse; mês-skréjam). Tačiau atskirai apie priegaidès žymėjimą nei ižangoje, nei skyriuje apie kirčiavimą autorius nekalba, išsiaiškinti diakritikų reikšmes teko tyrimo metu. 
Norėdamas raštu atspindèti garso kokybę A. Bezzenbergeris remiasi A. Bielensteinu, tačiau pastarojo pateiktame alfabete jam pritrūksta ženklų, todèl savaip juos adaptuoja, jungdamas su kitais, kurdamas naujus: pavyzdžiui, tais atvejais, kai negalejjo nustatyti, ar garsas ilgas, ar trumpas, A. Bezzenbergeris naudoja abu - ilgumo ir trumpumo - ženklus:

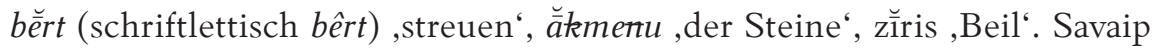
A. Bezzenbergeris išskiria atvejus, kada kirčio vieta neatitinka kirčiuoto pirmojo skiemens taisyklès. Tokias balses autorius pažymi paryškintuoju

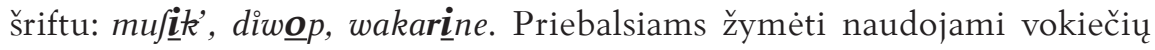
kalbos rašybos ženklai: $w$, sch, $t$ sch. Nuosekliai žymimas priebalsių minkštumas $(k, t, \pi, r)$.

A. Bezzenbergerio kuršininkų kalbos pavyzdžiuose naudojami rašybos ženklai pateikti lentelèje, ị kurią nėra įtrauktos grafemos, nekeliančios abejoniu $\left(b, d, m, p^{2}\right)$ :

1 lentelè

\begin{tabular}{|c|c|c|c|c|c|}
\hline La. $k$. & $\begin{array}{c}\text { A. Bezzen- } \\
\text { bergeris }\end{array}$ & $\begin{array}{l}\text { Pavyzdžiai iš } \\
\text { A. Bezzenber- } \\
\text { gerio darbo }\end{array}$ & La. $k$. & $\begin{array}{c}\text { A. Bezzen- } \\
\text { bergeris }\end{array}$ & $\begin{array}{l}\text { Pavyzdžiai iš } \\
\text { A. Bezzenber } \\
\text { gerio darbo }\end{array}$ \\
\hline$a$ & $\mathrm{a}$ & man & $c$ & $\mathrm{z}$ & piz mâju \\
\hline $\bar{a}$ & $\begin{array}{l}\text { â } \\
\text { á }\end{array}$ & $\begin{array}{l}\text { sâna } \\
\text { lázis }^{3}\end{array}$ & $\check{c}$ & tsch & waretschau \\
\hline $\boldsymbol{e}$ & e & es & $j$ & i & dõmáju \\
\hline$\rho$ & ä & wäls & $k$ & $\mathrm{k}$ & tik \\
\hline $\bar{e}$ & á & ziláka & $\underset{k}{\boldsymbol{k}}$ & $\mathrm{k}$ & škíbi \\
\hline$\overline{\boldsymbol{e}}$ & $\begin{array}{l}\text { ê } \\
\text { é }\end{array}$ & $\begin{array}{c}\text { mês } \\
\text { pazéla }\end{array}$ & $l$ & 1 & maldas \\
\hline$i$ & $\mathrm{i}$ & pi manis & $\underline{l}$ & $t$ & netátu \\
\hline$\overline{\boldsymbol{\imath}}$ & $\begin{array}{l}\hat{1} \\
1\end{array}$ & $\begin{array}{l}\text { grîsti } \\
\text { dzívs }\end{array}$ & $n$ & $\mathrm{n}$ & ne \\
\hline $\boldsymbol{u}$ & $\mathrm{u}$ & biju & $s$ & s & spárnis \\
\hline$\overline{\boldsymbol{u}}$ & $\begin{array}{l}\hat{\mathrm{u}} \\
\mathrm{u}\end{array}$ & $\begin{array}{c}\text { jûras } \\
\text { bút }\end{array}$ & $\check{s}$ & sch & tieschum \\
\hline$o$ & $\begin{array}{c}\text { o ilgas } \\
\text { ŏ trumpas }\end{array}$ & $\begin{array}{c}\text { sutwertojis } \\
\text { mŏnẽru }\end{array}$ & $v$ & $\mathrm{w}$ & fuwis \\
\hline
\end{tabular}

2 Taip pat rašybos lentelejje nebus nurodytas minkštasis $r(r)$, nes, pasak A. Bezzenbergerio, jis būdingas tik Melnragès ir Karklès gyventojų kalbai.

3 Skirtingais kirčio ženklais žymimos priegaidès, žr. skyrių Fonetinès ypatybès. 


\begin{tabular}{|c|c|c|c|c|c|}
\hline La. $k$. & $\begin{array}{l}\text { A. Bezzen- } \\
\text { bergeris }\end{array}$ & $\begin{array}{c}\text { Pavyzdžiai iš } \\
\text { A. Bezzenber- } \\
\text { gerio darbo }\end{array}$ & La. $k$. & $\begin{array}{l}\text { A. Bezzen- } \\
\text { bergeris }\end{array}$ & $\begin{array}{l}\text { Pavyzdžiai iš } \\
\text { A. Bezzenber- } \\
\text { gerio darbo }\end{array}$ \\
\hline uo & $\begin{array}{l}\text { ů nekirč. } \\
\text { õ kirč. }\end{array}$ & $\begin{array}{l}\text { Jalů } \\
\text { ötra }\end{array}$ & $z$ & 1 & barfda \\
\hline$a i$ & $\begin{array}{l}\text { ái pailg. } \\
\text { pirm. komp. } \\
\text { ai }\end{array}$ & $\begin{array}{l}\text { gáise } \\
\text { laiks }\end{array}$ & $\check{z}$ & Ich & difchu \\
\hline$a u$ & $\begin{array}{l}\text { áu } \\
\text { au } \\
\text { ód } \\
\text { ou }\end{array}$ & $\begin{array}{c}\text { náudes } \\
\text { daudf } \\
\text { óukst' 'hoch' } \\
\text { louk }\end{array}$ & - & $\begin{array}{l}\text { ' - balsio } \\
\text { redukcija; } \\
\text { po priebal- } \\
\text { sio einančio } \\
\text { balsio trum- } \\
\text { pumas }\end{array}$ & $\begin{array}{c}\text { tur' ('Ich habe') } \\
\text { beieda'ms }\end{array}$ \\
\hline$e i$ & $\begin{array}{l}\text { éi } \\
\text { ei }\end{array}$ & $\begin{array}{c}\text { méile } \\
\text { keiferu }\end{array}$ & - & $\begin{array}{c}\text { e, i, u }- \\
\text { redukuotas } \\
\text { balsis }\end{array}$ & $\begin{array}{c}b^{e} r^{e}, d u^{i} j a m, \\
d \ddot{a} g^{u}\end{array}$ \\
\hline ie & $\begin{array}{l}\text { i kirč. } \\
\tilde{e}^{6} \text { nekirč. }\end{array}$ & $\begin{array}{l}\text { dfidat } \\
\text { pradẽm }\end{array}$ & & $\begin{array}{l}\text { à, è - dvi- } \\
\text { garsiai su } \\
\text { trumpuoju } \\
\text { balsiu }^{7}\end{array}$ & kálna, lénke \\
\hline$g$ & g & gribija & - & $\begin{array}{c}\text { kartu } \\
\text { žymimas } \\
\text { trumpumas } \\
\text { ir ilgumas }\end{array}$ & 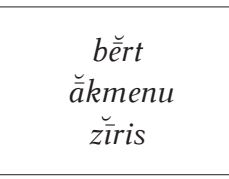 \\
\hline$g$ & 逢 & mage & & & \\
\hline$n$ & $\mathrm{n}$ & asinus & & & \\
\hline
\end{tabular}

\section{Tekstai}

A. Bezzenbergeris yra pirmasis, užrašęs kuršininkų kalbos pavyzdžių ne tik pavieniais žodžiais ar frazėmis, bet ir ištisais tekstais. Jo darbe pateiktos kelios trumpos dainelès iš Karklès, dvi ilgesnès apimties pasakos iš Kurže-

4 óu, ou vietoje $a u$, au būdingi tik Šarkuvos gyventojų kalbai (Bezzenbergeris 1888, 31). Plg. J. Plakis: âugstums, laũku (Pḷākis 1927, 49, 65).

5 Pasitaikè tik vienas atvejis tekste. Apie tekstų užrašymo būdą žr. skyrių Tekstai.

6 Kartais toks žymejjimas randamas kirčiuotuose skiemenyse - mẽsts 'Stadt', tačiau šiais atvejais tokiu būdu žymima priegaidè.

7 Plg. J. Plakis šiais atvejais kalba apie metatoniją: kâlns, bet kaĩ ni; gâlds, bet gatdi (Pḷākis 1927, 14). 
mès (Bartos) ir keturi nedideli tekstai iš Kuršiuc nerijos. Šiame straipsnyje pavyzdžiai iš Karklès ir Melnragès nenagrinèjami, jie A. Bezzenbergerio darbe pateikiami lyginti. Tekstus iš Kuršiu nerijos autoriui papasakojo Johannas Albertas Engelinas, žvejys iš Preilos, buvęs Nidos švyturio prižiūrètojas. Trijų iš šių tekstų vertimai ị lietuvių kalbą yra pateikti D. Kiseliūnaitès sudarytame tautosakos rinkinyje „Pamarių sakmès“ (Kiseliūnaitė 2010, 65, 85, 225). Pagal žanrą tokius tekstus rinkinio įvado autorè Lina Būgienè apibūdina kaip buitinius pasakojimus su atsirandančiais „,sakmiškais“, tam tikrą antgamtinę veikejju patirtị liudijančiais elementais; juose apibūdinamos mitinès būtybès arba ịvykiai, sudarantys siužetini pasakojimo branduoli - klaidinimą, vaidenimąsi ir pan. (Kiseliūnaitė 2010, 29-30). Nepaisant tekstų trumpumo, juose yra vertingos etnografinès ir lingvistinės informacijos, kuri liudija vardo $P \bar{u} k i s^{8}$, kuršininkų Juodkrantės pavadinimo Šatenurte (< vok. Schwarzort) (plačiau Bezzenberger 1887, 221-222; Kiseliūnaitė, Simutyte 2005, 46-47) vartojimą, kuršininkų tikejjimus, krikščionybès ir senųjų tikejjimų konkurenciją kuršininkų pasąmoneje ${ }^{9}$.

Nors A. Bezzenbergeris fonetikos apraše nurodo, kad kuršininkai redukuoja galūnes, jo pateiktuose tekstuose žodžiai dažniausiai rašomi su gramatiškai atkurtomis galūnèmis: Mana taitis ar mamu gâja nu Préilu piz Nidas; Es turiu fchîgi Schätnurtá. Pagâju nu Préilu nu fẽgaris trís, ir kal es pi Schtällmaker sawa fchîgi atsiliku, atgẩ man fẽgar's dewini. Tačiau autorius nepaaiškina, ar taip užrašytos galūnès atspindi tikrąii tarimą, ar jos buvo jo paties atkurtos, siekiant, kad užrašyti tekstai būtų geriau suprantami.

Dar daugiau kalbos faktų fiksuojama pagrindinejje knygos dalyje - kalbos studijoje, kurią sudaro 7 dalys: mokslas apie garsus (ị šią dali autorius įtrauke informaciją apie priegaides ir kirčiavimą), žodžių daryba, mokslas apie galūnes (linksniavimas ir asmenavimas), sintaksè, vietiniai kalbos skirtumai, leksika, papildymai.

Dèl paplitimo laikytinas kuronizmu (plg. la. pūķis 'aitvaras, kaukas') (Kiseliūnaitė 2010, 24).

9 Dar XIX a. pabaigoje - XX a. pradžioje kitataučiams etnografams kuršininkai atrodè nepaprastai prietaringi, tačiau tuo pat metu pamario gyventojai buvo nuoširdžiai tikintys aktyvūs bažnyčios lankytojai (plačiau Kiseliunaitė 2010, 21-23). 
3. Fonetinès ypatybès

Kuršininkų kalbos fonetikos ypatybėms A. Bezzenbergeris skyrè atskirą knygos dalį - „Apie garsų mokslą“ (Zur Lautlehre):

1. XIX a. pastebima galūnių redukcija. A. Bezzenbergeris pažymi, kad nekirčiuotuose galiniuose skiemenyse vietoj $a$ ir $u$ girdimas $e$, tačiau prieš ji priebalsiai nėra palatalizuojami, arba šiose pozicijose balsis trumpeja iki nulinio: galde (G. sg. galda), naudes (G. sg. naudas), sẽv' (N. sg. sieva), bráutsch' 'ich fahre' (praes. 1 p.). A. Bezzenbergeriui pavyko surinkti pakankamai pavyzdžių ir atkurti linksniavimo ir asmenavimo paradigmas.

2. Dar viena ryški ypatybè, kurią pastebejjo A. Bezzenbergeris, yra siaurojo $e$ suartejjimas su $i$ nekirčiuotuose skiemenyse: nigribu (la. b. k. negribu) 'ich will nicht', pic (pēc), upi (auch up') (N. sg.) (upe) 'Fluß'. Šią ypatybę užfiksavo ir kiti kuršininkų kalbos dokumentuotojai: J. Plāksis (1927, 16), J. Endzelīns (1931, 574).

3. A. Bezzenbergeris užfiksavo ir priebalsių išmetimą. Išmetami po tautosilabinių priebalsiai $v, n$. Ši ypatybė kuršininkų kalboje reiškiasi reguliariai (Kiseliūnaitė 2018, 86): mels (melns), piles (pilns), wäls (velns), wila (vilna), duris (durvis), gálla (galva), ziläks (cilvēks), ziris (cirvis). Žodyje bers (bērns) pastebèta priešinga asimiliacija - išmetamas $r$ : bäns (šalia bấrns) (plg. bẹ̆r (n)s Plāķis 1927, 50, la. b. k. bèrns). Šis atvejis aptiktas tik pateikejo iš Šarkuvos kalboje.

4. Kita akustinè savybė, kuriai A. Bezzenbergeris skiria daug dèmesio, yra anaptiksė - balsių įspraudimas po mišriųjų dvigarsių nidiškių kalboje. Šią ypatybę autorius aptaria, parodo įvairavimą ir pažymi specialiais diakritikais: dar ${ }^{e} b s$ (darbs), al ga (alga), kal $n s$ (kalns), dureti (durt). A. Bezzenbergeris pateikia daug pavyzdžių, kur ịterpiamas balsis įvairiose vietose: tiek prieš redukuotą galūnę, tiek ne, tiek vardažodžiuose, tiek veiksmažodžiuose. A. Bezzenbergeris girdèjo balsiu ịterpimą ir po m: ame $\int$ chas (lie. amžius) 'Leben',

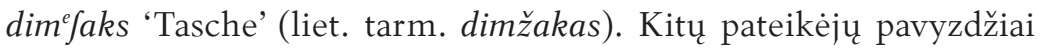
rodo variantus su įterptu balsiu ir be jo (Kiseliūnaite 2005, 140141). Vèliau anaptiksė ima nykti, tai savo darbe liudija J. Plakis (Plāķis 1927, 17).

Atskirame priede prie šios dalies A. Bezzenbergeris trumpai aptaria kirčiavimą. Jis pažymi, kad kuršininkų tarmejje yra stumtine (gestoßen) ir 
tęstinè (gedehnten) priegaidès. Trečiosios priegaidès, kurią A. Bezzenbergeris vadina halbgestoßen, jam rasti nepavyko.

Kaip jau minėta, priegaidžių žymėjimas nėra tiksliai aprašytas paties autoriaus, tačiau jo pavyzdžiuose priegaide ir kirtis žymimi nuosekliai tiek kirčiuotuose, tiek nekirčiuotuose skiemenyse. Stumtinė priegaidė žymima vienodai -' (kádu, wisái, jáuns, nepadarís, atsidfít, júdfi, Préilu, pradéje), o tęstine priegaide žymima skirtingai: dažniausiai - ^ (pi tâs, atgầ, fchî̀i, trûdni, jûras, jêma), tačiau dvibalsyje ie tęstinè priegaide žymima - ẽe (pẽns, dwẽlis, mẽsts), dar dažniau šiuo ženklu žymimas dvibalsis ie nekirčiuotoje pozicijoje.

A. Bezzenbergerio nustatytųjų priegaidžių atitikmenys bendrinèje latvių kalboje būtų tokie: plg. lázis, káds - $\mathrm{ME}^{10}$ lâcis, kâds; jûra, mês - $\mathrm{ME}$ jüra, mẽs).

A. Bezzenbergeris pastebejjo, kad trumpinant balsį, ypač prieš $r$ (dărbs), priegaidè pasikeičia, pirmojo dvigarsio komponento balsis trumpejja ir spūdis, visas ar iš dalies, pereina ị priebalsị.

Kirčio vieta, kaip būdinga latvių kalbai, yra pirmajame skiemenyje, tačiau kuršininkų kalboje yra išimčių, visos jos aptinkamos skoliniuose iš

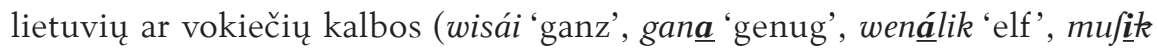
'Musik').

\section{4. Žodžių daryba}

Šioje trumpoje dalyje (3 puslapiai) A. Bezzenbergeris trumpai pristato žodžių darybos atvejus: katoikonimų sudarymo priesagas (-enize; -iniks), moterų pavardžių galūnes (Šarkuvoje - -ena: Blõdena, Nidoje, Preiloje - -ine: Blodine), abstraktų (Karklèje vartojama priesaga -schina, -schena vietoj -schana; nerijoje tokių nerasta, čia vartojama priesaga -ủms), deminutyvų (pavyzdžiui, mot. g. -elis/-ilis/-ele/-ile: mergêlis / mergilis / mergel' / mergele / mergile), prieveiksmių darybą. Daugiau dèmesio jis skiria atvejams, kai kuršininkų kalbos taisyklè nesutampa su latvių rašytinès kalbos norma. A. Bezzenbergeris pastebejjo, kad kuršininkų kalboje priešdèliuose išlaikomos senosios ilgosios prielinksnių formos nů, pi, off (nůkrist 'herabfallen', pisáuca 'er rief', offwerti 'aufreihen'), bet jos trumpinamos pačiuose prielinksniuose: $n u, p i, u f$ (us kůku 'auf den Baum', uf tõ

10 Mülenbachs K. 1923-1932. Latviešu valodas vārdnīca. 
jûras 'aus der See', pi manis 'zu mir', nu mutes 'aus dem Mund'). Ilguosius balsius prielinksniuose A. Bezzenbergeris rado tik Karklejje, Melnrageje, Pilkopoje (pabrèždamas, kad pateikèjas iš Pilkopos prastai kalbejjęs latviškai) (nů debeschu 'aus den Wolken', pi manis 'zu mir', úfzä'lt 'aufheben', off uzůle 'auf die Eiche').

\section{Morfologinès ypatybès}

Didžiausią A. Bezzenbergerio studijos „Apie Prūsijos latvių kalbą“ dalị sudaro morfologijos aprašas, kuriame jis atskirai aptaria kiekvieną kalbos dalį.

Aprašydamas daiktavardị, A. Bezzenbergeris pateikia daiktavardžiu linksniavimo paradigmas (a (nams), $\bar{a}$ (růka), ja (bralis), ja (Jeme), $n, s$ (akmittš, akmittis, akmitts; mênesis, rudinis, suns, tesmins, údiens), $u$ kamieną (lädus, mädus, lietus, dängus) ${ }^{11}$. Jis atkreipia dèmesị i kamienų mišimą: kuršininkų kalboje $i$ kamieno daiktavardžiai perejo i j $j \bar{a}$ kamieną: plg. ause, aze, awe, smilkte, suwe. A. Bezzenbergeris rekonstruoja linksniavimo paradigmas, atrinkdamas reikalingas formas iš skirtingų leksemų. Po paradigmomis jis detaliai paaiškina, kokiais pavyzdžiais rėmėsi atkurdamas linksnị.

Nuo XX a., stiprejjant vokiečių kalbos įtakai, kuršininkų kalboje vis labiau ịsigalejjo analitinių formų vartojimas. Šią tendenciją pastebejjo ir A. Bezzenbergeris, jo pateiktose daiktavardžiu paradigmose lokatyvo reikšme vartojamos prielinksninès konstrukcijos su is/iš + G. konkuruoja su ịprastu lokatyvu: if jûres; isch mutes; isch tewis, isch tâ nama, bet kůká, tiklá, ziemá, bafnizá. Po pusšimčio metuc J. Plakio pateiktoje paradigmoje inesyvo reikšme vartojamos beveik vien prielinksninès konstrukcijos, išskyrus kelis konkuruojančius atvejus (Plakis 1927, 21-28). Tyrinėdama paskutiniosios kuršininkų kartos atstovų kalbą, Christliebe El Mogharbel pastebėjo, kad vienaskaitos formose dar matoma konkurencija, o daugiskaitos lokatyvas yra retas, jo vietoje dažniausiai vartojama analitine forma (Mogharbel 1993, 128). Kuršininkès Hertos Paul-Deckait tekstuose lokatyvas vartojamas daug rečiau negu prielinksninè konstrukcija (Kiseliūnaitè, Ivanickaja 2015, 217).

11 Dabartinèse latvių kalbos gramatikose šiuos kamienus atitinka $a, \bar{a}, j a, \bar{e}$, priebalsinis ir $u$ kamienas. 
A. Bezzenbergeris nerekonstruoja paprastųiu būdvardžiŭ, pavyzdžiui, labs, laba; disch, difcha; matsch, fatsch, paradigmų, pateikdamas pavyzdžiu prie atitinkamų daiktavardžių paradigmų aprašymų ir pažymėdamas, kad jų linksniavimas sutampa su daiktavardžių $a^{-}, \bar{a}-, j a-$ kamieniais. Jis atskirai pateikia įvardžiuotinių būdvardžių paradigmą. A. Bezzenbergeris neturẻjo pakankamai pavyzdžiu atkurti visas moteriškosios giminès formas, todèl kai kurių linksnių formos pateiktos skliaustuose, vèliau jis išaiškina, iš kokių kitų būdvardžių nustatė moteriškosios giminès būdvardžio wäzá 'die alte' linksnius.

Skaitvardžius nuo 11 iki 19 autorius laiko lituanizmais. Jis užfiksavo dviskaitos formą ir pateikè skaitvardžio dui paradigmą su visais pastebėtais fonetiniais ir morfologiniais variantais ${ }^{12}$ :

Bon dui fenme ich folgende fajuas:

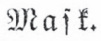

Mont, dui, duji

Ben. duju NP

Dat. dujims, dui

Sinjtr. dujis, dui

2ffé dujus, dui
Tremt.

dui LF t. $\mathfrak{a}_{*}$, dujas LF, dujes NP, dujis SII, N duju

dujams E, LF, duijems SII, dujäms SIII, du ijam KI, dujam LF, dujem KI, KIII, NP, duiem NS, dui SIII, LF, NP

dujes NP, dui LF, NP

\section{1 pav.}

A. Bezzenbergeris pristato kai kurių asmeninių ir parodomųjų ịvardžių linksniavimo paradigmas. Pažymima, kad savybiniai įvardžiai vartojami nekaitoma forma: mana bérni (N. pl.), mana sẽvai (D. sg.), ar sawa brâli (In. sg.), mana brâlis (N. sg.).

Knygos dalis, skirta veiksmažodžiui, yra neịprastos struktūros. Iš pradžių A. Bezzenbergeris trumpai aprašo asmenavimą. Jis remiasi A. Bilensteino latvių kalbos asmenavimo tipų klasifikacija. Asmenavimo tipai vadinami klasėmis. A. Bezzenbergeris pažymi, kad iš dvylikos klasių kuršininkų kalboje likusios šešios. Toliau poskyriuose pagal laikus pristatomas asmenavimas: esamasis, būtasis ir būsimasis, atskirai kiekviename poskyryje aptariami sangrąžiniai veiksmažodžiai. A. Bezzenbergeris neklasifikuoja

12 Iš šio pavyzdžio matyti, kad formų ịvairavimą lemia vartojimo teritorija, kurią rodo pateikejju pavardžių santrumpos: NP - Fischerwirt Peleikis in Nidden; SIII - Wirt Lauzining aus Schwarzort; E - Johan Albert Engelien, al. Eglien aus Preil (früher Leuchtfeuerwärter in Nidden, jetzt Fischer in Preil), KI, KIII - in Karkelbek ansäßigen "Kuren”. 
veiksmažodžiu pagal jų struktūrą, bet medžiagą išdėsto pagal asmenavimo tvarką. Vis dèlto tam tikros struktūrinès sistemos laikomasi: iš pradžių pateikiami nepriesaginiai veiksmažodžiai, paskui priesaginiai, tačiau priesaginių ir nepriesaginių veiksmažodžių pavyzdžiai nėra kaip nors aiškiau vieni nuo kitu atskiriami.

A. Bezzenbergeris pastebejjo, kad vartojamos dvejopos sangrąžinès daugiskaitos 1 ir 2 asmenų formų galūnès - -mis, -tis (sukamis 'wir drehen uns', pälldatis 'ihr badet euch') ir -més, -tés (mílamés 'wir lieben uns', raugatés 'ihr seht euch (um)'). Pastarąsias formas autorius tapatina su lietuviškomis:-mès, nordlit. -mås; -tés) (Bezzenberger 1888, 88).

Atskirai A. Bezzenbergeris aptaria bendratị ir išvestines veiksmažodžio formas: debityvą, liepiamąją ir tariamạją nuosakas. Jis pastebi, kad debityvo kuršininkų kalboje beveik nèra (priešingai nei pateikejjų iš Karklès ir Melnragès kalboje), vietoj jo vartojamos konstrukcijos su turet + inf. (es turu iti 'ich muß gehen', tu turi tõ bernuõf dabati 'du muß auf das Kind warten'), arba wajag + inf. (man wáig pirrkti 'ich muß kaufen', man wái g tõ berenu dabati 'ich muß auf das Kind achten'). A. Bezzenbergeris nurodo, kad lietuviškos ir latviškos tariamosios nuosakos formos konkuravo. Šarkuvoje ir Pilkopoje tariamosios nuosakos pirmojo asmens priesaga nepasieke visiškai lietuviškos formos, t. y. liko -tsche ir -tschu (sazätschu 'ich wurde sagen', finätsche 'ich wüßte'), jis tai paaiškina kaip lietuviško -tschau ir latviško -tu paradigmų išlyginimą. Kitose Kuršiu nerijos vietose buvo vartojamas sulietuvèjęs priesagos ir galūnès segmentas -tschau (warätschau 'ich könnte', daritschau 'ich würde tun', finatschau 'ich wüßte').

\section{Sintaksè}

Šis skyrius, paremtas pavieniais pastebejjimais, nėra didelis (5 puslapiai). Čia A. Bezzenbergeris skiria dèmesio žodžių junginiams ir prielinksninėms konstrukcijoms. Autorius pastebėjo, kad kuršininkų kalboje daugiskaitoje prielinksniai gali būti vartojami su įvairiais daiktavardžių linksniais, kaip ir vienaskaitoje, o latvių kalboje daugiskaitoje prielinksniai vartojami tik su datyvu-instrumentaliu: apaksch schõ akmimu 'unter diesen Steinen', us tẽs kůkis 'auf den Bäumen', us kưku 'auf den Baum'. Tą pati liudija J. Plakis (Pḷākis 1927, 39)

A. Bezzenbergeris pateikia vartojimo atvejus, kurie atsirado dèl lietuvių ar vokiečiuc kalbos įtakos: lituanizmais laiko pa + Gen. pa kůka 'unter 
einem Baum' (plg. žem. po medžio), ne bigribiju 'wollte nicht mehr', nebiwaru 'kann nicht mehr' ${ }^{13}$; germanizmais - $\underline{\text { nu }}$ difchas báimes 'aus großer Furcht', piz mâju 'nach Hause', wina bija példetîs 'fie was baden' = 'fie war baden gegangen' ir pan.

\section{Vietiniai kuršininkų kalbos skirtumai, genezé}

Atskirą knygos dali A. Bezzenbergeris skiria vietiniams kuršininkų kalbos skirtumams, t. y. regioniniams skirtumams pačioje nerijos gyventoju kalboje. Ši darbo dalis kuršininkų kalbos tyrinejjimams yra labai svarbi: pietinejje Kuršiu nerijos dalyje kuršininkų kalba buvo prie išnykimo ribos, todèl po A. Bezzenbergerio darbų regioninių skirtybių nebebuvo užfiksuota, šiandien to nebeįmanoma patikrinti ir palyginti.

A. Bezzenbergeris mano, kad regioniniai skirtumai kuršininkų kalboje atsirado dèl dviejų priežasčių:

1. Dèl administracinio padalijimo pagal valsčius (Klaipėdai ir Žuvininkams (Fischhausen)).

2. Skirtingo kontaktų su kaimynine lietuvių kalba pobūdžio.

Autorius pastebejjo, kad žmonių, gyvenančių tarp Klaipėdos ir Palangos, kalba artimesnė rašytinei latvių kalbai negu Kuršių nerijos gyventojų kalba (K, M kalba turi wái $\left(\mathrm{Kn}^{14}-w a\right)$, mafe (ne mage), minkštąi i $r$ : jûra, nevartoja prielinksninès lokatyvo konstrukcijos if + Gen., išlaikė debityvą (jámáz). Pasak A. Bezzenbergerio, Melnragès ir Karklès gyventojai laikė save lietuviais ${ }^{15}$.

Atskirai autorius aptaria Kuršiu nerijos kuršininkų kalbos skirtumus. Nerijoje kalbos plotas buvo taip pat dalijamas ị dvi dalis, kurias skyrė riba, einanti tarp Nidos ir Pilkopos, mūsų laikais sutampanti su Lietuvos ir Rusijos siena ${ }^{16}$. Kalbos skirtumus tarp šių plotų A. Bezzenbergeriui patvirtino

13 A. Bezzenbergeris laiko šią ypatybę tiek morfologine (Bezzenbergeris 1888, 33), tiek sintaksine (Ibid., 108). Sintaksès ypatybe tikriausiai laikoma dèl to, kad latvių kalboje veiksmo trukmès pabaigai reikšti vartojamos analitinès formos su prieveiksmiu vairs. Kuršininkų kalboje ši funkcija reiškiama lietuvišku priešdèliu ne-, jo vartojimą pastebejjo ir J. Plakis (Pl̄ākis 1927, 69).

$14 \mathrm{~K}$ - Karklè, M - Melnragè, Kn - Kuršių nerija.

15 "Die Mellneragger und Karkelbeker Letten nennen sich dagegen Litauer, lediglich aber, wie sie mir erklärten, weil sie in Liatauen wohnen” (Bezzenberger 1888, 135).

16 Tai yra buvusi riba tarp Klaipėdos ir Žuvininkų (ankst. Žiokų) valsčių. Ši riba vèliau buvo ir valstybiu siena tarp Vokietijos ir Lietuvos. 
ir Šarkuvoje gyvenęs pateikejjas, kuris teigè, kad Pilkopos ir Šarkuvos kuršininkų kalba yra vienoda, bet skiriasi nuo Nidos ir Juodkrantės tuo, jog pastarųju plotų kalbos vartotojai šneka daug greičiau. A. Bezzenbergeris šio teiginio nepatvirtino, bet pateikẻ kitus pastebėtus skirtumus: šiaurinèje dalyje balsiai $\bar{a}$ ir $\bar{e}$ junginyje " $r+$ Konsonant" sutrumpèja, o pietinejje išlieka ilgi; pietinejje dalyje išnyko didžiausias asmenavimo klasių skaičius; skiriasi pietinès ir šiaurinès dalies tariamosios nuosakos formos (žr. skyrių Morfologines ypatybès); randama skirtumų ir leksikoje: vok. Stadt piet. pi'lss[ä]ts, šiaur. mẽsts, vok. Doch - piet. ju’mts, šiaur. stáks ir t. t. Pietinès dalies kalba, pasak A. Bezzenbergerio, dèl kai kurių minètų ir kitų bruožų labiausiai panaši ị tamniekų tarmę $e^{17,18}$.

Šiame skyriuje autorius ne tik aprašo kalbos skirtumus, bet ir pateikia informacijos apie vietovardžiu etimologiją ir nerijos gyventojus: kaip jie save vadina ir kodèl, kada ir kiek truko gyventoju migracija iš Kuršo ${ }^{19}$.

A. Bezzenbergerio pastebejjimai leidžia daryti prielaidą, kad pietinès dalies kalbos panašumą su tamniekų tarme lèmè migracijos procesai: spėtina, kad ten kèlèsi šeimos iš šiaurès Kuršo. Šiaurinè dalis galèjo būti kuršininkų apgyvendinta vèliau ir joje apsigyveno pietinès Kuršo dalies palikuonys, kurie, žinoma, maišèsi ne tik su pilkopiškiais, bet ir su kito kranto gyventojais lietuviais. O Karklès ir Melnragės gyventojų kalba iš visų kuršininkų artimiausia bendrinei kalbai, čia tamniekų pẻdsako nerandama, tačiau apie migracijos procesus ị šias vietas dar turime per mažai duomenų.

17 "Sākumā par tāmnieku izloksnèm sauca visas Kurzemes izloksnes; pēc tam tiklab Kurzemè, kā arī Vidzemē runājamās lībiskās izloksnes. Tagad par tāmnieku izloksnēm parasti sauc tikai Kurzemes lībiskās izloksnes" (Rudzīte 1964, 29).

18 "Die Sprache von Sarkau und vielleicht teilweise auch diejenige von Pillkopen steht in Gegensatz zu dem übrigen Preußisch-lettische in einigen charakteristischen Punkten auf Seiten des "Tahmischen"” (Bezzenberger 1888, 131); "Das Preußisch-lettische ist ein in mehrere Mundarten zerfallendes selbständiges Glied der westkurländisch-lettischen Sprache und schließt sich, als Ganzes betrachtet, zunächst an die südwestkurländischen Mundarten an, während zugleich sein südlichster Teil tahmisch gefärbt ist” (Ibid., 133).

19 A. Bezzenbergeris laiko migracijos pradžia XV a., nes jau tada Ordino diduomenè skundèsi dideliu migrantų antplūdžiu: "Im Verlaufe des 15. Jahrhunderts wurden wiederholt Klagen kurländischer Ordensgebietiger über Auswanderungen aus Kurland nach Preußen laut; die Zahl der ausgewanderten Kuren wird in ihnen als eine beträchtliche angegeben" (Ibid., 136). 


\section{Leksika}

Leksikos dali sudaro žodynas (688 žodžiai, iš jų 340 vardažodžiu), i kuri įeina leksemos, nesančios tekstuose ir kalbos studijos dalyse. İ žodyną pateko kalbos pavyzdžiai, kurių A. Bezzenbergeris pats negirdejjo, jie surinkti iš kitų rašytinių šaltinių: Voelkelio žodžių rinkinio, Šarkuvos bažnyčios 1664-1672 m. knygos, iš kurios žodžius pateikè Adolfas Rogge, pagalbininkų atsiųstų kalbos pavyzdžių. Didžiąją dali žodžių A. Bezzenbergeriui atsiuntė Paulas Manleitneris, surinkęs juos Juodkrantėje. Leksemas, kurios A. Bezzenbergeriui nebuvo žinomos ir aiškios, jis pažymejo ' $\dagger$ ' (44). Matyti, kad autoriui informacijos patikimumas buvo labai svarbus.

\section{Pataisymai, papildymai}

Daugelis papildymų prie knygos atsirado tada, kai A. Bezzenbergeris dar kartą nuvyko į Karklę (kai knyga jau buvo atiduota spausdinti), kur susipažino su keturiais gyventojais (darbe žymimi KI, KII, KIII, KIV), emigrantais iš Kuršo, kurie labai rūpinosi savo kalba. Matyt, iš pačiu pateikejju A. Bezzenbergeris sužinojo, kad KI ir KIV senelis imigravo iš Kuržemès, KII ir KIII apie savo šeimos / šeimų atsiradimą nieko nežino ${ }^{20}$. Tai leidžia daryti prielaidą apie kai kurių kuršininkų kalbos vartotojų vẻlyvą atsikèlimą i šias vietoves iš Kuršo, tai paaiškintų ir kalbos artumą bendrinei latvių kalbai. Atsikèlę gyventojai atvyko jau sulatvèję. A. Bezzenbergeris pabrèžè, jog tik nedidelèje pietinèje Karklès dalyje šeimos kalba buvo latvių (kuršininkų), šiaurinejje buvo kalbama lietuviškai. Tačiau nauji pateikejai paaiškino, kad žvejybai patogesnè yra latvių kalba, nes trumpesnè, tad net šiaurinès dalies gyventojai, taip pat ir Nemirsetos, žvejyboje kalbejjo latviškai. Šiu pateikejjų informacija papildè A. Bezzenbergerio medžiagą.

Išvados

A. Bezzenbergerio darbas yra vertingas dèl gausios nykstančios kalbos medžiagos dokumentavimo ir mokslinio preciziškumo. Jo studija - tiek

\footnotetext{
20 "Der Großvater von K1 und der von V4 sind aus Kurland eingewandert, K2 und K3 wissen dagegen nichts von einer Einwanderung ihren Familien. Sehr beachtenswert ist, dass nur in dem südlichen kleineren teile Karkelbeks das Lettische, in dem nördlichen dagegen das Litauische Familiensprache ist" (Bezzenberger 1888, 165).
} 
tiriamoji dalis, tiek tekstų rinkinys, tiek žodynèlis sudaro XIX a. vartotų kuršininkų kalbos pavyzdžių rinkinį.

Ši rašytini šaltini galima laikyti patikimu šnekamosios kalbos dokumentu, nes jo autorius ne tik atidžiai rinko ir perteikẻ informaciją iš pateikeju, bet ir komentavo, išskirdamas visus fonetinius, morfologinius ir leksinius variantus, atvejus, kai jis pats negirdejo tarimo, abejojo ar maté kitokį prieštaravimą.

Šis rašytinis šaltinis laikytinas patikimu ir dèl kruopščiai parengtos rašybos sistemos, kuri leidžia skaitytojui gana tiksliai atkurti kuršininkų kalbos fonetiką ir jos įvairavimą.

Ypač vertintinas A. Bezzenbergerio indèlis fiksuojant pietinès nerijos dalies kalbos pavyzdžius, kurie yra unikalūs, nes po jo daugiau iš ten kuršininkų kalbos pavyzdžių nebuvo užrašyta.

Ypač svarbios A. Bezzenbergerio pastabos apie regioninius kuršininkų kalbos skirtumus, remiantis jomis galima daryti prielaidas apie migracijos procesus. Kruopščiai užfiksuoti gausūs fonetiniai variantai leidžia spèti, kad į Kuršių neriją žmonès kèlèsi iš skirtingų Kuršo tarmių plotų.

A. Bezzenbergerio darbas padeda atkurti ano meto kuršininkų kalbos raidos stadiją: prasidejjusią, bet dar toli nepažengusią galūnių redukciją, anaptiksę, kuri vẻliau išnyko; kitus ryškius Kuršo tarmiu fonetikos bruožus. Lygindami jo pateiktus pavyzdžius ir komentarus su vèlesniais šaltiniais, galime ịvertinti prasidejjusį lietuvių kalbos poveikį kuršininkų kalbos morfologijai ir pastebimą, tačiau dar neįsigalejjusią vokiečių kalbos įtaką sintaksei.

\section{Literatūra}

Bezzenberger 1885 - Adalbert Bezzenberger. Lettische Dialekt-Studien. Göttingen: Vandenhoeck und Ruprecht's Verlag.

Bezzenberger 1887 - Adalbert Bezzenberger. Die Kurische Nehrung und ihre Bewohner. Leipzig.

Bezzenberger 1888 - Adalbert Bezzenberger. Über die Sprache der preußischen Letten. Göttingen: Vandenhoeck und Ruprecht's Verlag.

Endzelīns 1979 - Jānis Endzelīns. Par kurseniekiem un viṇu valodu. 1931. Darbu izlase III (1). Rīga, 571-578.

Ivanickaja 2017 - Arina Ivanickaja. XVIII a. kuršininkų kalbos žodžių rankraštinis registras. Res Humanitariae XXI, 12-42.

Ivanickaja A., Kiseliūnaitė D. 2015. Kuršių nerijos kuršininkų tarmės nykimo požymiai: daiktavardžių linksniavimo pokyčiai rašytiniuose paminkluose. Baltiška, tautine, 
regioninè savimone baltų literatūrose ir kultūrose. Vilnius: Lietuvių literatūros ir tautosakos institutas, 207-227.

Kiseliūnaitė 1998 - Dalia Kiseliūnaitė. Kai kurie kuršininkų tarmės veiksmažodžių bruožai nuo A. Bezzenbergerio iki šių dienų. Baltistica 5. Priedas, 127-140.

Kiseliūnaitė 2005 - Dalia Kiseliūnaitė. Balsių ịterpimas Vakarų Lietuvos lietuvių ir latvių (kuršininkų) tarmèse. Baltai ir ju giminaičiai. Tiltai. Priedas. Mokslo darbai 26, 139-144.

Kiseliūnaitè, Simutytė 2005 - Dalia Kiseliūnaitė, Laima Simutytè. Kuršiu nerijos vietu vardai. Orts- und Flurnamen auf der Kurischen nehrung. Klaipèda: Klaipėdos universiteto leidykla.

Kiseliūnaitė 2010 - Dalia Kiseliūnaitė. Pamariu sakmès. Klaipėda: Klaipėdos universiteto leidykla.

Mogharbel 1993 - Christliebe El Mogharbel. Nehrungskurisch. Dokumentation einer moribunden Sprache. Frankfurt am Main: Wissenschaftliche Buchhandlung Theo Hector GmbH\&Co.

Mülenbachs 1923-1932 - Kārlis Mülenbachs. Latviešu valodas vārdnīca.

Pietsch 1991 - Richard Pietsch. Deutsch-kurisches Wörtebuch. Lüneburg: Verlag Nordostdeutsches Kulturwerk.

Plāķis 1927 - Juris Plāķis. Kursenieku valoda. Latvijas universitātes raksti XVI. Rīga.

Rudzīte 1964 - Marta Rudzīte. Latviešu dielektologija. Latvijas valsts izdevniecība. Rīga.

Schiller, Kiseliūnaitė 2015 - Christiane Schiller, Dalia Kiseliūnaitė. Ein nehrungskurischer Text im Forschungszentrum Deutscher Sprachatlas in Marburg. Das Blatt Nidden 30084. Archivum Lithuanicum 17, 379-403.

Strakauskaitė 2011 - Nijolè Strakauskaitè. Etnofilologiniai Prūsijos lietuvių identifikavimo kontekstai (XIX a. antroji pusè - XX a. pradžia). Acta Historica Universitatis Klaipedensis, t. XXIII. Sud. V. Safronovas, N. Strakauskaite, L. Motuzienè. Klaipėda, 145-157.

\section{Arina Ivanickaja}

\section{ADALBERT BEZZENBERGER - RESEARCHER AND DOCUMENTER OF THE KURSENIEKU LANGUAGE}

Summary

The seriously endangered Kursenieku language has never had a writing system, but there were attempts to record it by using various characters of other languages. Adalbert Bezzenberger's work Über die Sprache der preußischen Letten (1888) became the first professional study of the Kursenieku language. The work is comprised of a quite detailed description of the phonetical, morphological and lexical features of that time, the provided examples of the Curonian Kursenieku dialects are compared to the examples of Melnragè and Karklè Kursenieku language. Bezzenberger is the only documenter of the Kursenieku language, who managed to record language examples from the southern part of the Curonian Spit (Pilkopa, 
Rasyte, Kuncai), which now belongs to Russia, but even then he was able to find just a few speakers, as that part of the Spit was already Germanised. The article briefly introduces sections of Bezzenberger's work in order to discover and emphasize the features of the Kursenieku language of that time, which could have later changed due to the influence of other languages.

Bezzenberger's work is valuable for the documentation of the abundant materials on the endangered language and scientific accuracy. His studies, including the research part, set of texts and the glossary, comprise the collection of the $19^{\text {th }}$ c. Kursenieku language examples.

Bezzenberger's work helps to restore the stage of the Kursenieku language development of that time: the beginning, but not yet advanced reduction of endings, anaptyxis, which later disappeared; other striking phonetical features of the Kursenieku dialects. The comparison of his examples and comments with later sources, allows to assess the emerging impact of the Lithuanian language on the morphology of the Kursenieku language and the noticeable, but still not established, impact of the German language on syntax. 